\title{
Evaluation of Mung bean Germplasm for Resistance against Mung bean Yellow Mosaic Virus and Whitefly Population in Relation to Epidemiological Factors
}

\author{
Muhammad Aslam Khan, Sajjad Haider and Yasir Ali* \\ Department of Plant Pathology, University of Agriculture Faisalabad, Pakistan
}

Submission: September 07, 2018, Published: October 16, 2018

"Corresponding author: Yasir Ali, Department of Plant Pathology, University of Agriculture Faisalabad, Z.A. Hashmi Hall, Rom\#23D, UAF, Faisalabad, Pakistan; Tel: 00923076769321; Email: yasirklasra.uca@gmail.com

\begin{abstract}
Mung bean is attacked by several viral diseases but the most devastating is mung bean yellow mosaic virus (MYMV) and its vector Bemisia tabaci (Genn.) when occurred in severe condition. The vulnerable germplasm and conducive environmental conditions contribute towards severe epidemics of MYMV and its vector population. In present investigation, 12 varieties/lines were screened out and correlated with epidemiological factors (minimum and maximum temperature, relative humidity, rainfall and wind speed). Four varieties/lines namely NM-92, NM-2006, Azri 2006, and NM-121 were found most effective for cultivation under prevailing environmental conditions. All environmental factors were significantly correlated with MYMV disease severity and whitefly population except rainfall and wind speed. Maximum disease severity was recorded maximum at maximum temperature $\left(38^{\circ} \mathrm{C}\right)$, minimum temperature $\left(28^{\circ} \mathrm{C}\right)$ and relative humidity $(65 \%)$. Similarly, whitefly population increased with increase in maximum and minimum temperature and relative humidity ranging from $30-38{ }^{\circ} \mathrm{C}, 20-28^{\circ} \mathrm{C}$ and $45-65 \%$, respectively. It was concluded that with progress in temperature (minimum and maximum) and relative humidity, MYMV disease incidence and its vector population also increased.
\end{abstract}

Keywords: Bemisia tabaci; Epidemiological factors; MYMV; Resistance

Abbreviations: MYMV: Mung Bean Yellow Mosaic Virus; HR: Highly Resistant; R: Resistant; MR: Moderately Resistant; MS: Moderately Susceptible; AARI: Ayub Agricultural Research Institute

\section{Introduction}

Mung bean (Vigna radiata L.) belongs to family Fabaceae is famous for its rich protein seed contents which range between $22-24 \%$ ensure admirable digestibility and improved taste. It contains $24.7 \%$ protein, $0.6 \%$ fat, $0.5 \%$ ash and many vitamins like A, B, E, C and K [1]. Consumption of green mung beans has been studied to cure diseases i.e. diabetes, heart diseases, anemia, cancer, inflammation, digestion problems, and celiac diseases. It contains phytoestrogen which has various benefits in producing collagen, elastin and hyaluronic acid. All of these play an important role in acquiring healthier and younger skin. It can also prevent osteoporosis and relieve hot flashes [2].

It is an important pulse crop that can be grown twice a year i.e. spring and autumn and can withstand adverse environmental conditions [3]. Its production is influenced by many factors among them mung bean yellow mosaic virus (MYMV) disease is most significant, causing severe yield losses [4]. To overcome its production, evaluation of mung bean germplasm against MYMV for identification of resistance source under field conditions was carried out as genetic resistant is more important, environment eco-friendly way to regulate yellow mosaic virus.

Environment is an important component of disease epidemics, as weather influences disease development and plays crucial part in disease spread. Therefore, comprehensive study of environmental factors was required for developing a reliable disease prediction system consisting of environmental variables which explained $81 \%$ of the variability in MYMV disease development [5]. High rainfall during the month of July and less or no rain in the month of August were crucial for the disease development [2]. Work done so far, for the study of environmental conditions conducive for MYMV disease development is not sufficient; therefore, this study will be helpful for prediction of disease that will help the farmers in decision making regarding integrated management of the MYMV.

MYMV did not spread through seed, soil or contact but transmitted through vector whitefly in a persistent manner [6]. The whitefly population showed positive correlation with the 
disease development [7]. Disease incidence increased rapidly with the increase in the number of whitefly population [4]. The frequency of whitefly population increased due to excessive use of insecticides, as it has developed a resistance against whitefly [8]. Thus, the present study was designed to evaluate the mung bean germplasm under natural field conditions to identify new sources of resistance against mung bean yellow mosaic virus and its vector population and to determine the environmental conditions conducive to mung bean MYMV and whitefly population in the field.

\section{Materials and Methods}

Twelve mung bean genotypes namely NM-92, NM-2006, Azri 2006, NM-121, NM-54, NM-20-21, 014358, 014287, 014530, 07007, 058003 and NM-98 collected from Ayub Agricultural Research Institute (AARI), Faisalabad were sown for disease screening nursery in the Research Area of Department of Plant Pathology, University of Agriculture, Faisalabad following randomized complete block design replicated three times. Trial was not treated with any seed dressing chemical to increase the maximum chances of primary infection. Each test entry was planted in a row of 3 meter in length with $30 \mathrm{~cm}$ row-to- row distance. The planting was done on $16^{\text {th }}$ June 2016. One row of a most susceptible check (Kabuli mung) was sown after every ten test entries to enhance disease outbreaks.

\section{Data Regarding}

After initiation of first disease symptoms, disease progression was calculated on the bases of visual symptoms of disease at weekly intervals on each on twelve varieties. Data for disease severity were recorded using 0-5 rating scale as described by Bashir et al. [9] (Table 1). Disease incidence and whitefly population (\%) was recorded using method given by Khattak et al. [1]. Conformation of virus was done through grafting method described by Akhtar $\&$ Haq [10].

Table 1: Disease rating scale (0-5) for MYMV disease.

\begin{tabular}{|c|c|c|c|}
\hline Grade & \% Infection & Visual Symptoms & Infection Category \\
\hline 0 & All plant free of virus symptoms & Complete absence of symptoms & Highly resistant \\
\hline 1 & $1-10 \%$ infection & Small yellowish spots scattered on some leaves & Resistant \\
\hline 2 & $11-20 \%$ infection & Yellowish bright spots common on leaves, easy to observe & Moderately resistant \\
\hline 3 & $21-30 \%$ infection & Yellowish bright specks common on leaves, easy to observe with & Moderately susceptible \\
\hline 4 & $30-50 \%$ infection & Bright yellow specks or spots on all leaves, minor stunting of plants & and less number of pods \\
\hline 5 & More than $50 \%$ infection & $\begin{array}{l}\text { Yellowing or chlorosis of all leaves on whole plant, shortening of in- } \\
\text { ternode, severe stunting of plants with no yield or few flowers and } \\
\text { deformed pods produced with small, immature and shriveled seeds }\end{array}$ & Highly Susceptible \\
\hline
\end{tabular}

$$
\text { Disease incidence }=\frac{(\text { No.of infected plants })}{(\text { Total number of plants })} \times 100
$$

\section{Correlation of environmental factors with MYMV dis- ease development}

Data of environmental conditions i.e. maximum and minimum air temperatures, relative humidity, rainfall, and wind velocity were collected from the meteorological station of the Department of Crop Physiology at (U.A.F).

\section{Statistical Analysis}

Statistical analysis was performed through statistical tests by using SAS/ STAT statistical software [11]. Data for disease incidence, whitefly populations and environmental parameters were analyzed through correlation and regression analysis to estimate the relationship with environmental factors and disease development. Epidemiological factors having statistically significant impact on disease development were graphically plotted.

\section{Results}

No line was found highly resistant (HR) and resistant (R) whereas; four varieties/lines namely NM-92, NM-2006, Azri 2006, and NM-121 demonstrated moderately resistant (MR) response against MYMV. Two varieties such as NM-54 and NM-20-21 exhibited moderately susceptible (MS) and six varieties showed susceptible (S) response against MYMV (Table 1).

\section{Relationship of environmental conditions with whitefly population}

Except rainfall and wind speed, all environmental factors showed significant positive correlation with MYMV disease incidence and whitefly population on different mung bean varieties (Table 2-4).

Table 2: Response of various mungbean varieties against different MYMV disease development.

\begin{tabular}{|c|c|c|c|}
\hline Serial \# & Varieties/Lines \# & Percentage Infection & Response \\
\hline 1 & NM-92 & $11-20 \%$ & MR \\
\hline 2 & NM-2006 & $11-20 \%$ & MR \\
\hline 3 & NM-121 & $11-20 \%$ & MR \\
\hline
\end{tabular}


Agricultural Research \& Technology: Open Access Journal

\begin{tabular}{|c|c|c|c|}
\hline 4 & Azri-2006 & $11-20 \%$ & MR \\
\hline 5 & NM-54 & $21-30 \%$ & MS \\
\hline 6 & NM-20-21 & $30-50 \%$ & MS \\
\hline 7 & 14538 & $30-50 \%$ & S \\
\hline 8 & 14287 & $30-50 \%$ & S \\
\hline 9 & 14530 & $30-50 \%$ & S \\
\hline 10 & 7007 & $30-50 \%$ & S \\
\hline 11 & 58003 & $30-50 \%$ & S \\
\hline
\end{tabular}

Table 3: Correlation of environmental conditions with mungbean yellow mosaic virus on different mungbean varieties/ lines.

\begin{tabular}{|c|c|c|c|c|c|}
\hline Name of Varieties & Max. Temp. $\left({ }^{\circ} \mathrm{C}\right)$ & Min. Temp. $\left({ }^{\circ} \mathrm{C}\right)$ & Relative Humidity (\%) & Rainfall (mm) & Wind Speed (Km/ha) \\
\hline \multirow{2}{*}{ NM-92 } & $0.70^{*}$ & $0.77^{*}$ & $0.79^{*}$ & $-0.11^{*}$ & $-0.38^{*}$ \\
\cline { 2 - 6 } & 0.021 & 0.05 & 0.01 & 0.02 & -0.04 \\
\hline \multirow{2}{*}{ NM-21-25 } & $0.72^{*}$ & $0.16^{*}$ & $0.80^{*}$ & $-0.16^{*}$ & 0.03 \\
\cline { 2 - 6 } & 0.01 & 0.05 & 0.05 & $-0.13^{*}$ & $-0.36^{*}$ \\
\hline \multirow{2}{*}{98001} & $0.75^{*}$ & $0.21^{*}$ & $0.83^{*}$ & 0.01 & 0.04 \\
\cline { 2 - 6 } & 0.02 & 0.04 & 0.03 & $-0.17^{*}$ & $-0.37^{*}$ \\
\hline \multirow{2}{*}{7007} & $0.69^{*}$ & $0.11^{*}$ & $0.77^{*}$ & 0.73 & 0.04 \\
\hline
\end{tabular}

*: Significant)

Table 4: Correlation of environmental conditions with whitefly population on different mungbean varieties/lines.

\begin{tabular}{|c|c|c|c|c|c|}
\hline Name of Varieties & Max. Temp. $\left({ }^{\circ} \mathrm{C}\right)$ & Min. Temp. $\left({ }^{\circ} \mathrm{C}\right)$ & Relative Humidity (\%) & Rainfall (mm) & Wind Speed (Km/ha) \\
\hline \multirow{2}{*}{ NM-92 } & $0.57^{*}$ & $0.92^{*}$ & $0.62^{*}$ & $-0.23^{*}$ & $-0.48^{*}$ \\
\cline { 2 - 6 } & 0.02 & 0.05 & 0.01 & 0.04 & -0.02 \\
\hline \multirow{2}{*}{ NM-21-25 } & $0.73^{*}$ & $0.18^{*}$ & $0.82^{*}$ & $-0.10^{*}$ & 0.02 \\
\cline { 2 - 6 } & 0.04 & 0.02 & 0.04 & 0.04 & $-0.40^{*}$ \\
\hline \multirow{2}{*}{98001} & $0.76^{*}$ & $0.19^{*}$ & $0.82^{*}$ & 0.01 & -0.04 \\
\cline { 2 - 6 } & 0.01 & 0.01 & 0.04 & $-0.15^{*}$ & $-0.38^{*}$ \\
\hline \multirow{2}{*}{7007} & $0.75^{*}$ & $0.21^{*}$ & $0.82^{*}$ & 0.77 & 0.04 \\
\hline
\end{tabular}

\section{Characterization of environmental factors conducive for MYMV disease development and whitefly population}

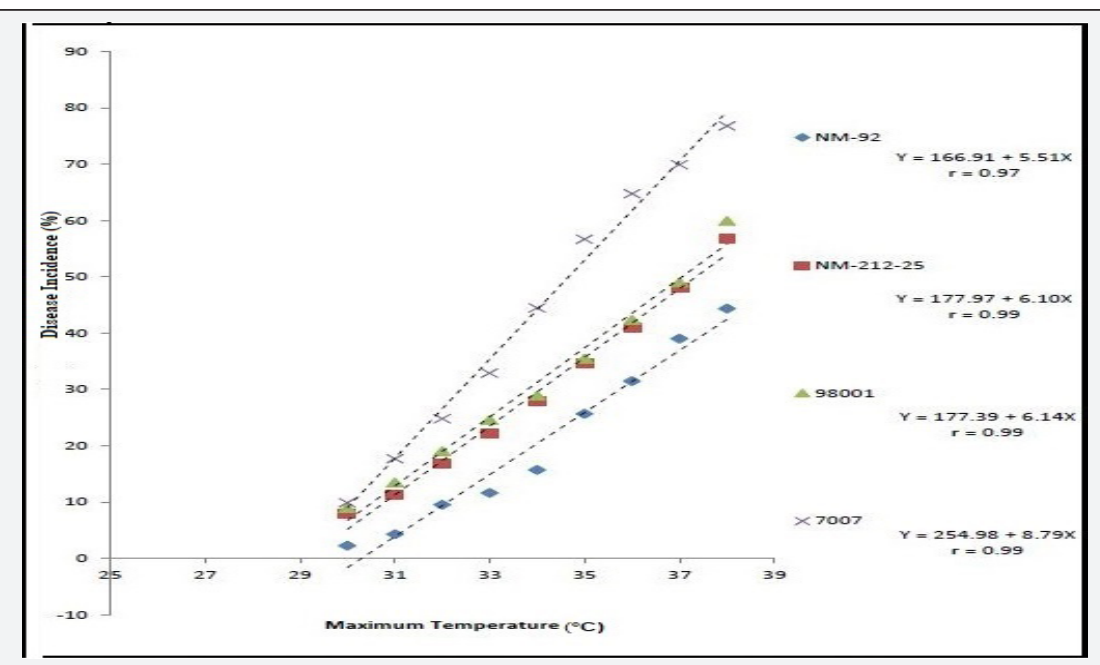

Figure 1: Relationship of maximum temperature $\left({ }^{\circ} \mathrm{C}\right)$ with MYMV incidence.

How to cite this article: Muhammad A K, Sajjad H, Yasir A. Evaluation of Mung bean Germplasm for Resistance against Mung bean Yellow Mosaic Virus and Whitefly Population in Relation to Epidemiological Factors. Agri Res\& Tech: Open Access J. 2018; 18(3): 556058. DOI: 10.19080/ARTOAJ.2018.18.556058. 
Four varieties/lines NM-92, NM-21-25, 98001 and 07007 were subjected to regression analysis to characterize the critical ranges of epidemiological conditions effective for MYMV disease development and whitefly population. It was found that all lines/ varieties indicated maximum disease incidence when maximum temperature increased from $30-38^{\circ} \mathrm{C}$. This relationship was best explained as indicated by their $r$ values $0.97,0.99,0.99$ and 0.99 respectively (Figure 1). Linear regression model best explained the positive relationship between disease incidence (\%) and minimum temperature. Maximum disease incidence (75\%) was demonstrated by genotype 7007 as compared to all other varieties at the same temperature. This relationship was best explained by their $r$ value 0.97 (Figure 2). A positive relationship was observed between relative humidity and disease incidence (\%). With every single unit increase in relative humidity disease incidence (\%) also increased against all four genotypes as indicated by their $r$ values $0.97,0.99,0.98$ and 0.98 , respectively (Figure 3). A negative relationship was observed between rainfall $(\mathrm{mm})$, wind speed $(\mathrm{km} / \mathrm{h})$ and disease incidence (\%) (Figure 4 \& 5).

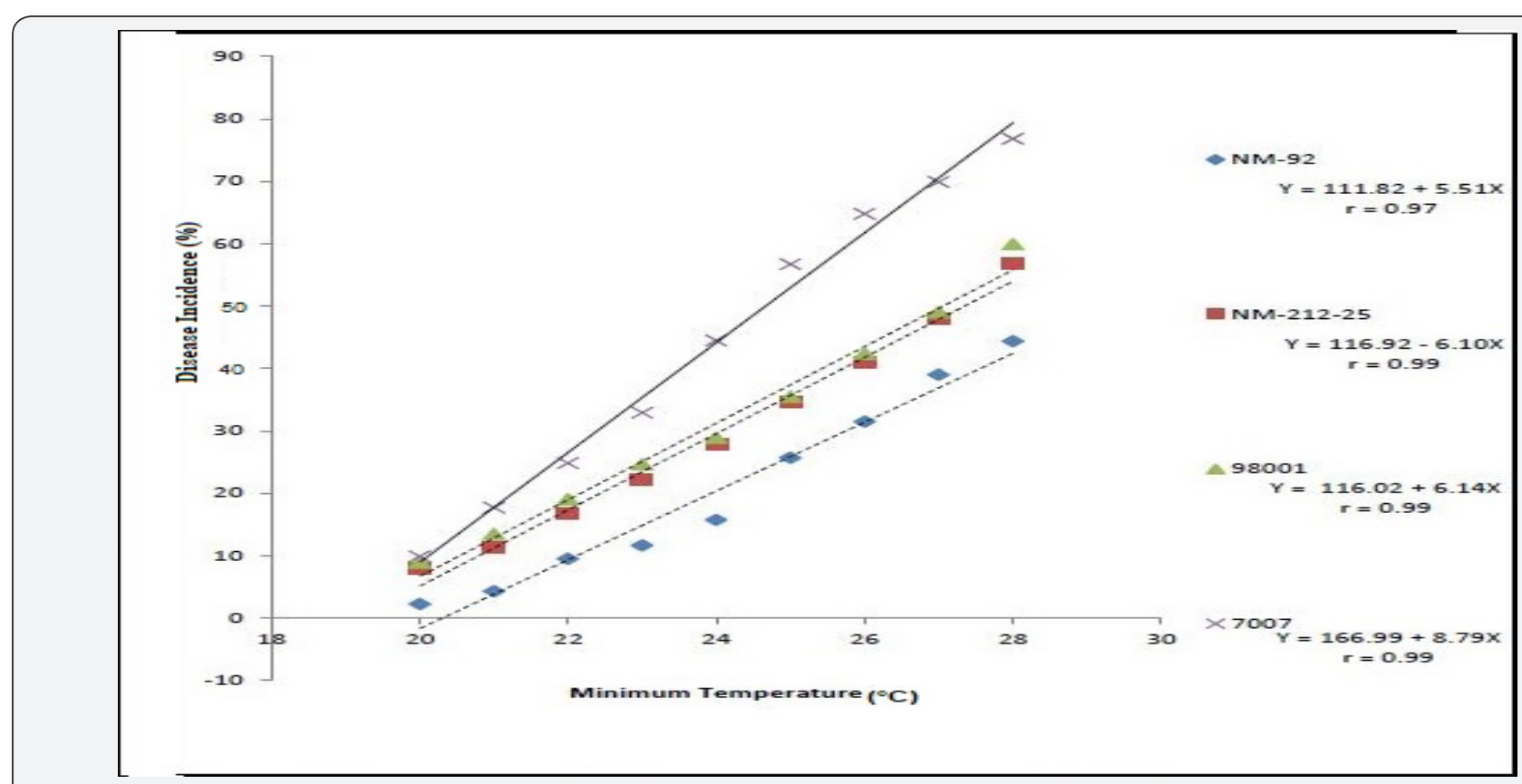

Figure 2: Relationship of minimum temperature $\left({ }^{\circ} \mathrm{C}\right)$ with MYMV incidence.

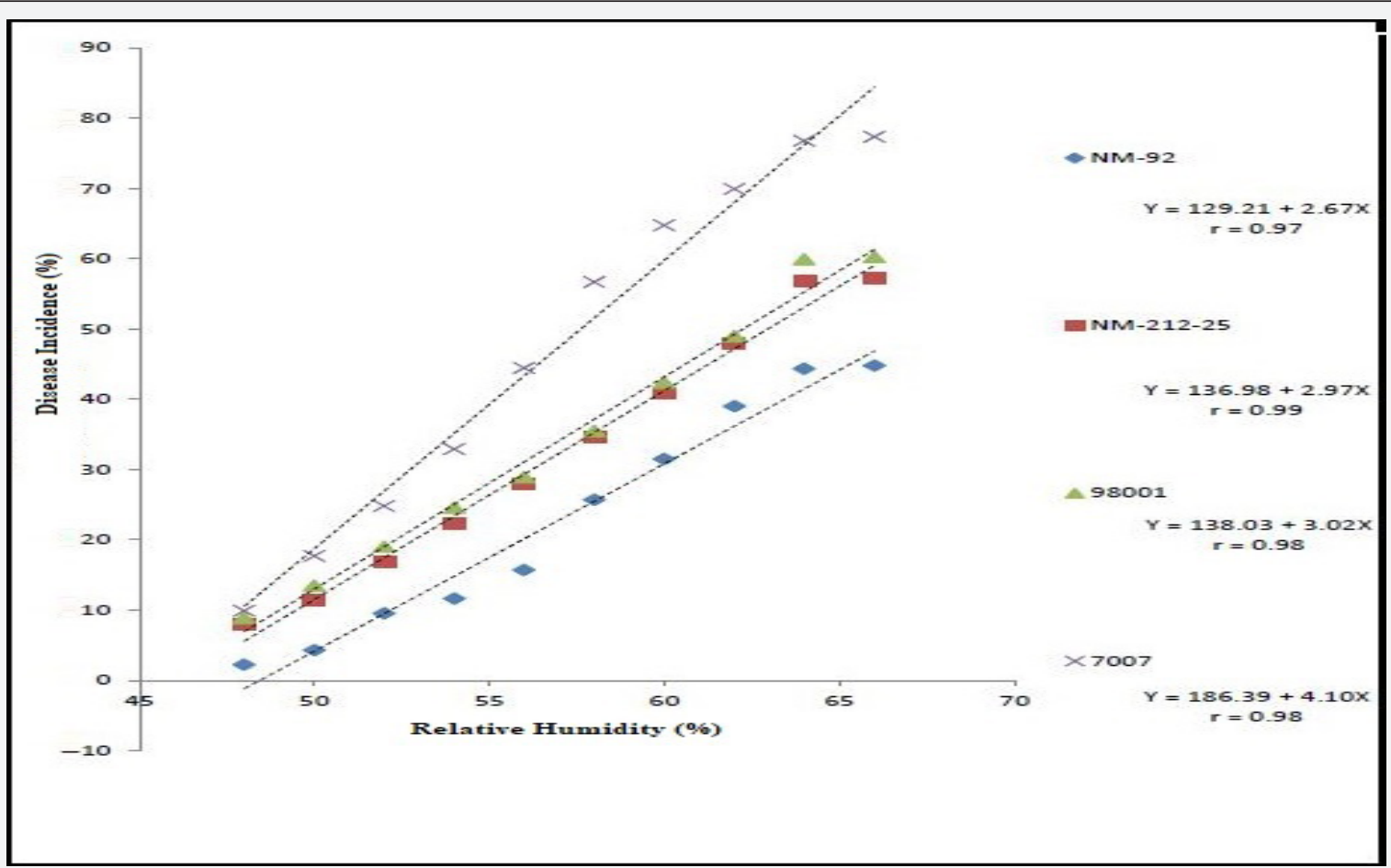

Figure 3: Relationship of relative humidity (\%) with MYMV incidence. 


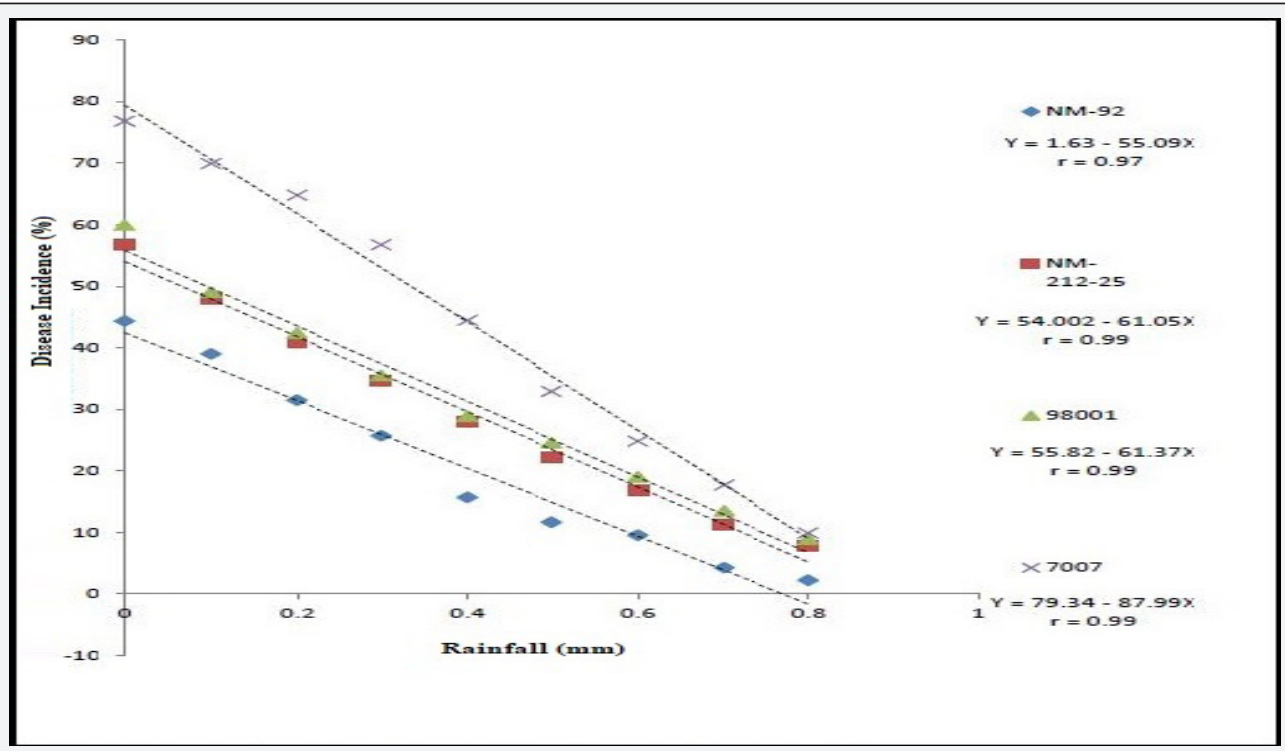

Figure 4: Relationship of rainfall $(\mathrm{mm})$ with MYMV incidence.

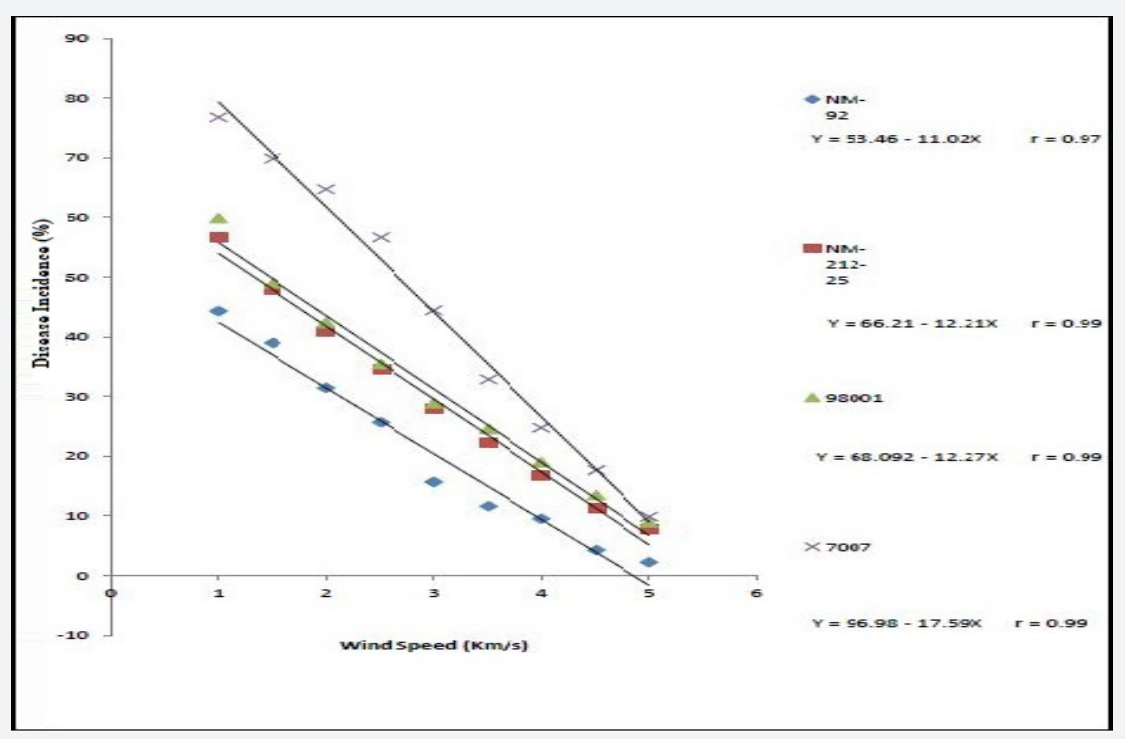

Figure 5: Relationship of wind speed $(\mathrm{km} / \mathrm{h})$ with MYMV incidence.

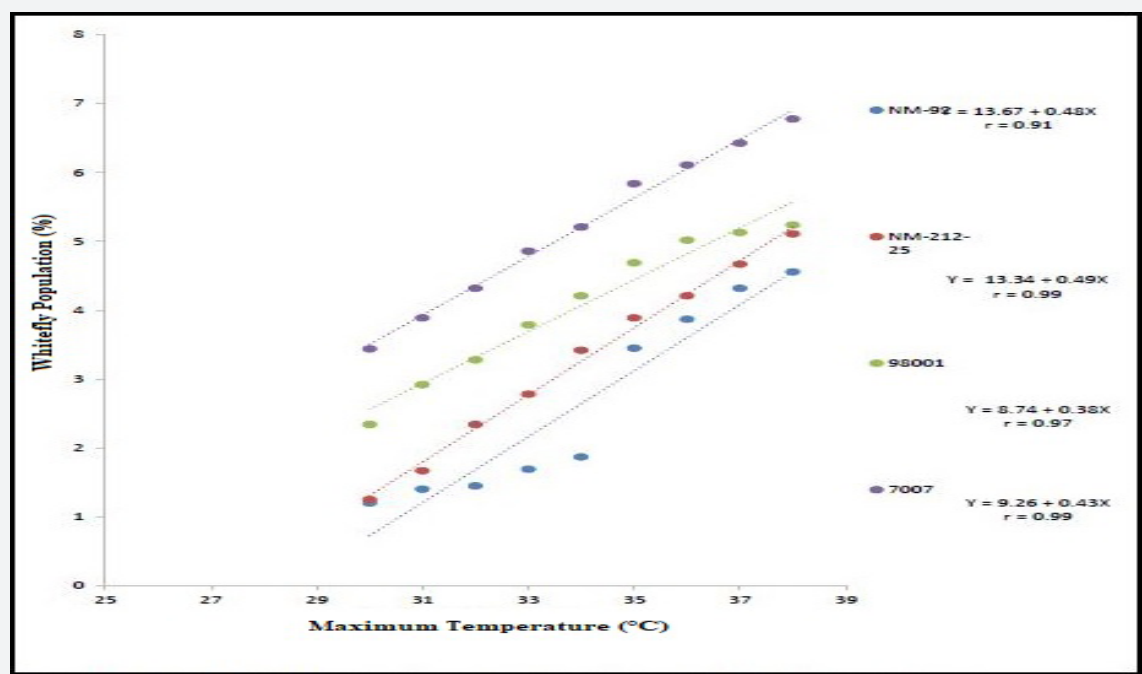

Figure 6: Relationship of maximum temperature $\left({ }^{\circ} \mathrm{C}\right)$ with whitefly population $(\%)$.

How to cite this article: Muhammad A K, Sajjad H, Yasir A. Evaluation of Mung bean Germplasm for Resistance against Mung bean Yellow Mosaic Virus and Whitefly Population in Relation to Epidemiological Factors. Agri Res\& Tech: Open Access J. 2018; 18(3): 556058. DOI: 10.19080/ARTOAJ.2018.18.556058. 


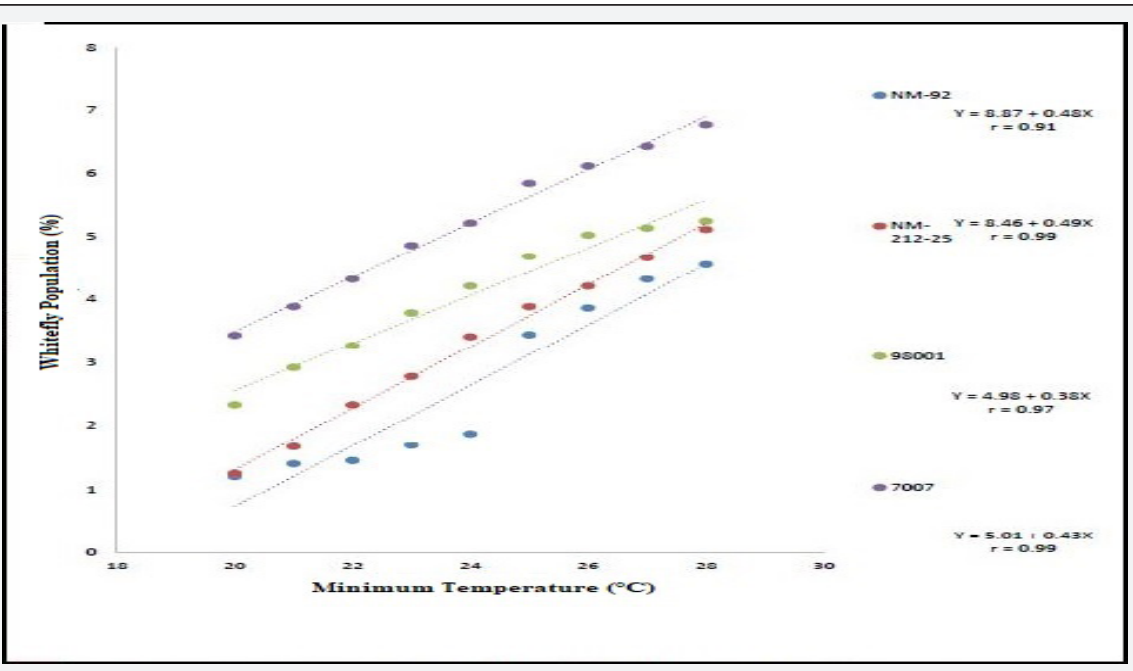

Figure 7: Relationship of minimum temperature $\left({ }^{\circ} \mathrm{C}\right)$ with whitefly population $(\%)$.

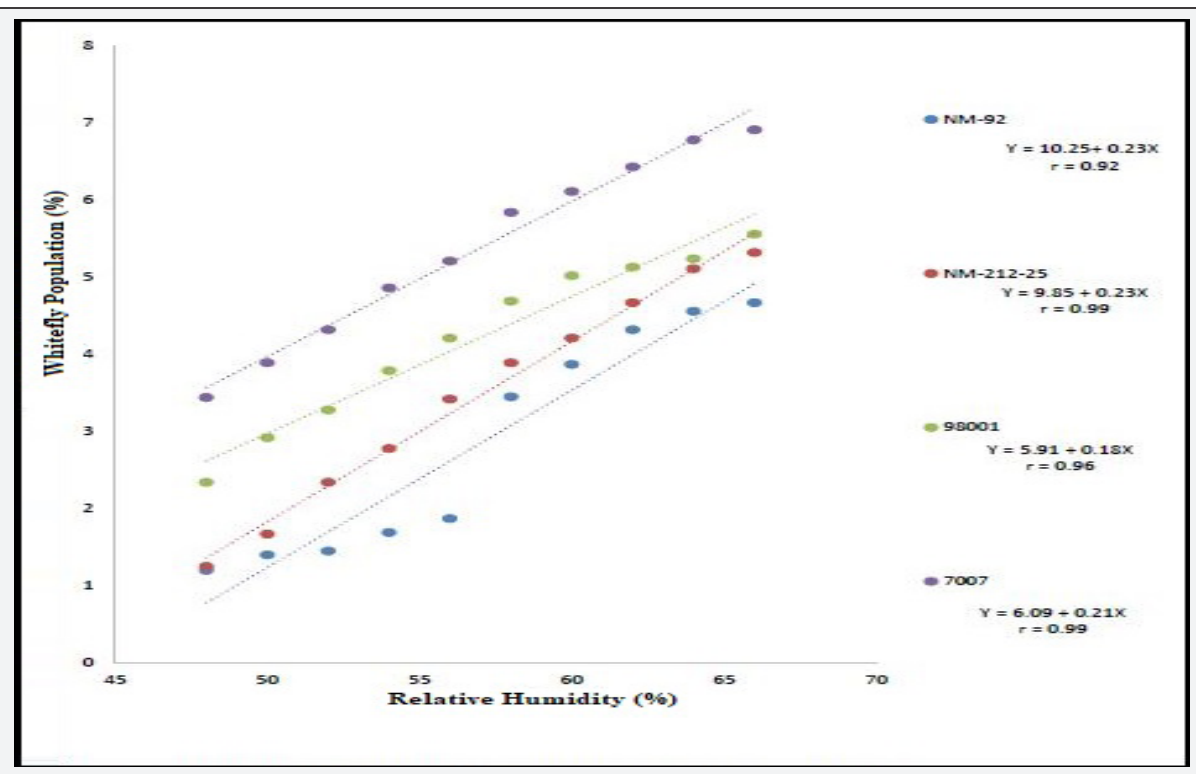

Figure 8: Relationship of relative humidity (\%) with whitefly population.

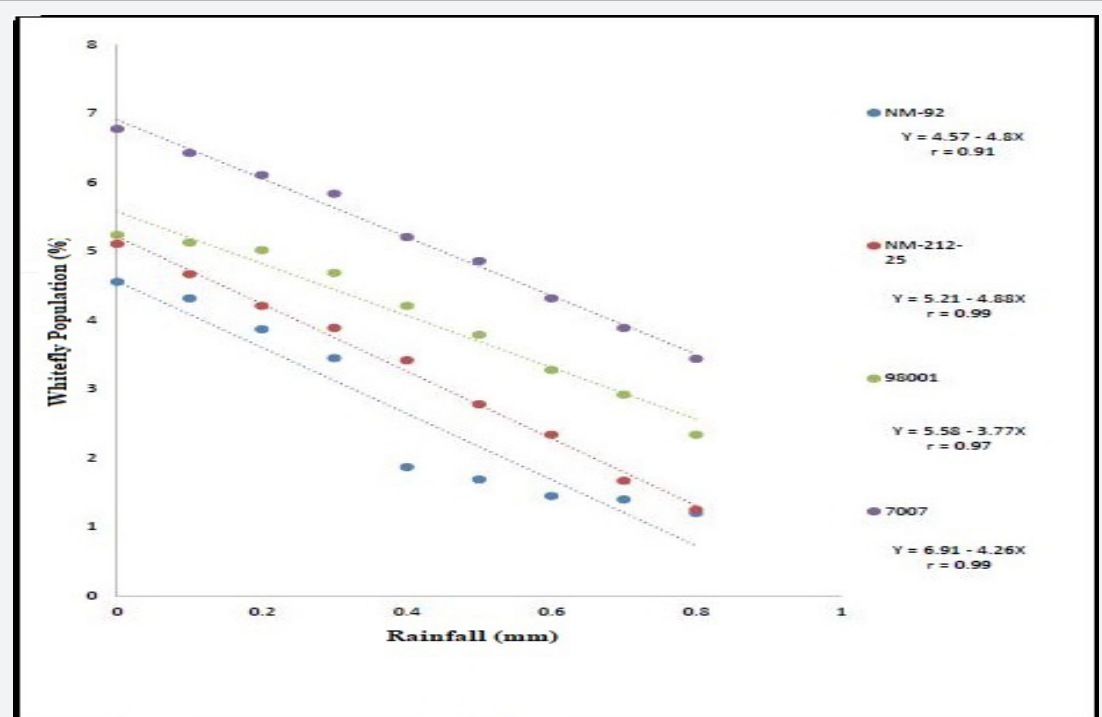

Figure 9: Relationship of rainfall $(\mathrm{mm})$ with whitefly population.

How to cite this article: Muhammad A K, Sajjad H, Yasir A. Evaluation of Mung bean Germplasm for Resistance against Mung bean Yellow Mosaic Virus and Whitefly Population in Relation to Epidemiological Factors. Agri Res\& Tech: Open Access J. 2018; 18(3): 556058. DOI: 10.19080/ARTOAJ.2018.18.556058 


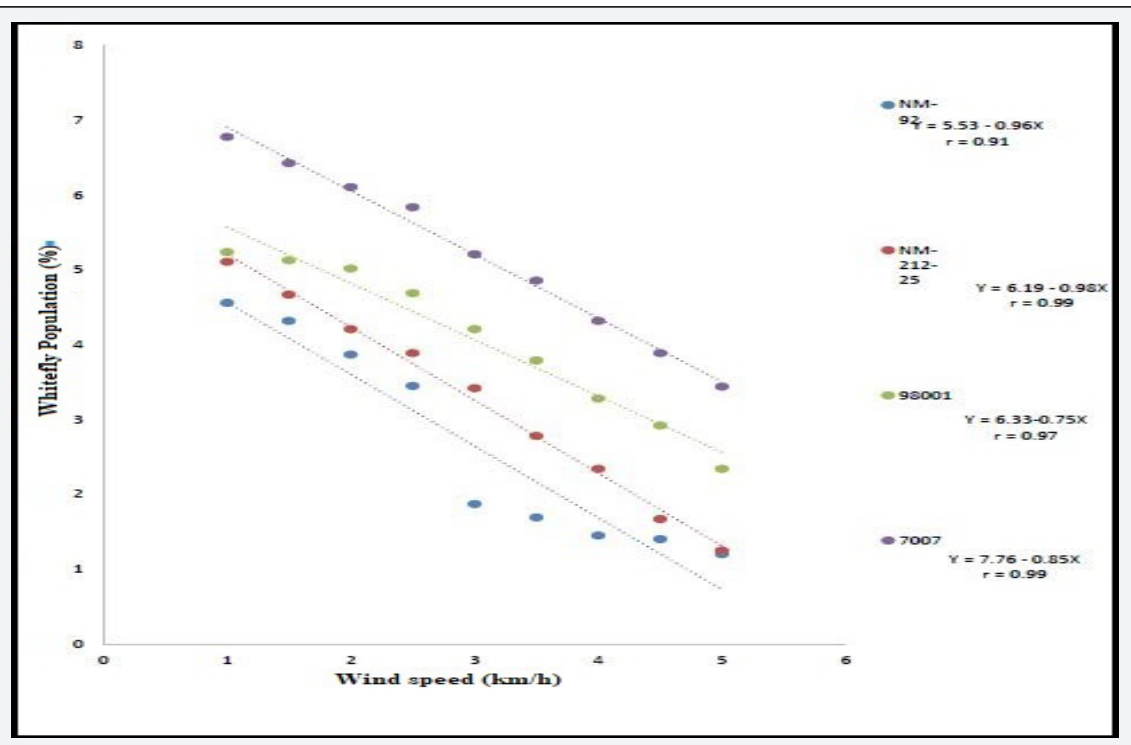

Figure 10: Relationship of wind speed $(\mathrm{km} / \mathrm{h})$ with whitefly population.

Different lines indicated different response to whitefly population. A positive relationship was observed between maximum and minimum temperature and relative humidity with whitefly population (\%). Maximum white fly population was observed at maximum temperature $\left(38{ }^{\circ} \mathrm{C}\right)$, minimum temperature $\left(26^{\circ} \mathrm{C}\right)$ and relative humidity (66\%) (Figure 6-8). Linear egression model showed the negative relationship between rainfall $(\mathrm{mm})$, wind speed $(\mathrm{km} / \mathrm{h})$ and whitefy population (\%). With every single unit increased in rainfall $(\mathrm{mm})$ and wind speed $(\mathrm{km} / \mathrm{h})$, whitefly population decrease (Figure $9 \& 10$ ).

\section{Discussion}

In the present investigations, an effort was made to exploit the sources of resistance in the available germplasm of mung bean. For this purpose, a set of germplasm was evaluated for $\mathrm{v}$ their response to yellow mosaic virus disease. It was found that disease severity increased with increase in the age of plants resulting in serious disease outbreaks of the susceptible lines. Out of 12 varieties/lines, none of the line showed highly resistant (HR) and resistant (R) response, only 4 lines showed moderately resistant (MR) response. Our results showed the similarity with the earlier findings of Bashir et al. [12], and Shad et al. [13], who demonstrated that resistance in mung bean against MYMV is rare. Bashir [14], screened 276 lines and only 10 lines 95013, C1/95-3-140, C1/94-04-19, C1/95-03-20, C1/95-3-8, C1/943-140, C1/94-4-26, C1/94-4-5, C5/95-4-5, C5/95-5-19 and C1/95-3-17 were rated as resistant. Shad et al. [13], found that there was no resistant line against MYMV and seven susceptible and 247 highly susceptible lines exhibited meager resistance in mung bean. Similarly, Rathi [15], evaluated 50 entries from mung bean germplasm along with the standard control $\mathrm{T} 44$ against white fly and MYMV disease under field conditions. The incidence of MYMV disease on tested entries varied from 1, 0 and 25.42 percent compared to 14.78 percent on $\mathrm{T}$ 44. Khan et al. [16], described that, according to the mean score of MYMV genotypes such as VC1560D, VC3902A and Berken were found susceptible (S), VC2272, Emerald, Pusa Baisaki moderately susceptible (MS), 6601 and NM92 found highly resistant (HR). Among 22F1 hybrid combinations, 12 were detected as susceptible and 10 moderately susceptible towards MYMV disease reaction. Lack of resistance necessitates the development of viral resistant varieties through genetic engineering and biotechnology in future.

Epidemiological factors play significant role in MYMV disease development and whitefly population. The results of present investigation are in line with the findings of Khan et al. [16], who exhibited that, maximum disease incidence and white fly population was observed at maximum and minimum temperature 37.92 and $17.7^{\circ} \mathrm{C}$, respectively. Livinder et al. [17], showed that, maximum and minimum temperature $34-35$ and $26-27{ }^{\circ} \mathrm{C}$ were found most effective for the MYMV disease development. Similarly, Nath [18], Khan et al. [6], and Srivastava \& Prajapati [19], reported positive correlation of relative humidity, rain fall and wind speed with the MYMV disease incidence.

The results of the present studies are also supported by the investigation of Bishnoi et al. [5]; Pun et al. [20]; Bhagat et al. [7], who observed that relative humidity played a crucial role in the multiplication of virus and its vector and in the spread of mung bean yellow mosaic disease. Ali et al. [3], also studied the effect of environmental factors and concluded that the maximum and minimum air temperature, relative humidity and wind speed had significant influence on disease incidence. Similarly, Singh \& Gurah [21], found that hot weather with little or no rainfall was conducive for multiplication of MYMV and Bemisia tabaci [22-24].

\section{References}

1. Khattak GSS, Saeed I, Shah SA (2008) Breeding high yielding and disease resistant mungbean (Vigna radiata (L.) Wilczek) genotypes. Pak J Bot 40(4): 1411-1417.

2. Jeon HY, Kim JK, Kim SK, Seo DB, Lee SJ (2016) U.S. Patent No. 9,265,707. U.S. Patent and Trademark Office, Washington, USA. 
3. Ali S, Khan MA, Habib A, Rasheed S, Iftikhar Y (2005) Management of yellow vein mosaic disease of okra through pesticide/bio-pesticide and suitable cultivars. Int J Agri Biol 7: 145-147.

4. Parihar AK, Kumar A, Dixit GP, Gupta S (2017) Seasonal effects on outbreak of yellow mosaic disease in released cultivars of mungbean (Vigna radiata) and urdbean (Vigna mungo). Indian J Agric Sci 87(6): 734-738.

5. Bishnoi OP, Singh M, Rao VUM, Ram R, Sharma D, et al. (1996) Population dynamics of cotton pests in relation to weather parameters. Indian J Entomol 58(2): 103-107.

6. Khan MA, Rashid A, Mateen A, Sajid M, Rasheed F, et al. (2012) Incidence of mungbean yellow mosaic virus (MBYMV), its epidemiology and management through mycotal, imidacloprid and tracer. J Agric Biol 3(11): 476-480.

7. Bhagat AP, Yadav BP, Prasad Y (2000) Rate of dissemination of okra yellow vein mosaic virus disease in three cultivars of okra. Indian Phytopathol 54(4): 488-489.

8. Ahmad M, Arif MI, Naveed M (2010) Dynamics of resistance to organophosphate and carbamate insecticides in the cotton whtefly Bemisia tabaci (Hemiptera: aleyrodidae) from Pakistan. J Pest Sci 83(4): 409-420.

9. Bashir M, Ahmad Z, Ghafoor ZA (2005) Sources of genetic resistance in mungbean and black gram against urdbean leaf crinkle virus (ULCV). Pak J Bot 37(1): 47-51.

10. Akhtar KP, Haq MA (2003) Standardization of a graft inoculation method for the screening of mungbean germplasm against Mungbean yellow mosaic virus (MBYMV). Plant Pathol J 19(5): 257-259.

11. SAS (1990) Institute Inc. SAS User's Guide to Statistics, Version 6, (4 $4^{\text {th }}$ edn), SAS Institute Inc., Cary, North Carolina, USA.

12. Bashir M, Zubair M (2002) Identification of resistance in urdbean (Vinga mungo) against two different viral diseases. Pak J Bot 34(1): 49-51.

13. Shad N, Mughal SM, Farooq K, Bashir M (2006) Evaluation of Mungbeen Germplasm for resistance against Mungbean Yellow Mosaic Begomovirus. Pak J Bot 38(2): 449-457.
14. Bashir M, Ahmad Z, Mansoor S (2003) Occurrence and distribution of viral disease mungbean and mashbean in Punjab, Pakistan. Pak J Bot 38(4): 1341-1351.

15. Rathi YPS (2002) Epidemiology, yield losses and management of major diseases of Kharif pulses in India. Plant Pathology and Asian Congress of Mycology and Plant Pathology. pp. 1-4.

16. Khan MA, Rasheed S, Ali S (2006) Evaluation of multiple regression models based on epidemiological factors to forecast Bemisia tabaci and mungbean yellow mosaic virus. Pak J Phytopath 2(18): 107-110.

17. Livinder K, Singh G, Sharma YR, Dhaliwal LK, Sarbjot K (2009) Meteorological factors influencing mungbean yellow mosaic virus epidemic in mungbean. Plant Dis Res 24(1): 81-82.

18. Nath PD (1994) Effect of sowing time on the incidence of yellow mosaic virus disease and whitefly population on greengram. Annu Agric Res 15(2): 174-177.

19. Srivastava AK, Prajapati RK (2012) Influence of weather parameters on outbreak of mungbean yellow mosaic virus in black gram (Vigna mungo L.) of bundelkhand zone of central india. J Agric Phy 12(2): 143151.

20. Pun KB, Sabitha D, Doraiswamy M (2000) Influence of weather factors on the incidence of okra yellow vein mosaic virus disease. J Agric Sci 13(1): 91-96.

21. Singh RA, Gurha SN (1994) Influence of cropping seasons on the incidence of yellow mosaic disease in mungbean genotypes. Indian J Pulses Res 7(12): 206-208.

22. Anjum MS, Ahmed ZI, Rauf CA (2006) Effect of Rhizobium inoculation and nitrogen fertilizer on yield and yield components of mungbean. Int J Agric Biol 8(2): 238-240.

23. Malathi VG, John P (2008) Mungbean yellow mosaic virus. Encyclo Virol ( $\left.3^{\text {rd }} \mathrm{edn}\right), 8: 364-372$.

24. Potter NN, Hotchkiss JH (1997) Food Science ( $5^{\text {th }}$ Edn), CBS Publishers, New Delhi, India, p. 403.

\section{Your next submission with Juniper Publishers will reach you the below assets}

- Quality Editorial service

- Swift Peer Review

- Reprints availability

- E-prints Service

- Manuscript Podcast for convenient understanding

- Global attainment for your research

- Manuscript accessibility in different formats

( Pdf, E-pub, Full Text, Audio)

- Unceasing customer service

Track the below URL for one-step submission https://juniperpublishers.com/online-submission.php 